\title{
THE INFINITIVE \\ IN THE SEMANTICAL-GRAMMATICAL ASPECT
}

\section{Handziuk O. M.}

\section{INTRODUCTION}

Linguistic literature nominates the infinitive a verbal formation. Under such a definition, this form was having to convince that grammatical categories typical for the verb are displayed in it. And also this must mean that the infinitive is able to perform primary verbal formally syntactic and semantic-syntactic functions. But even today, the infinitive is under an ambiguous interpretation. This contradictory form still causes opposite judgments, which are important in representation of the fundamental questions of grammar, for example, regarding the description of part of speech resources, the syntax of a complex and simple sentence, the category of modality, predicativity, etc ${ }^{1}$.

Various interpretations of the infinitive are dependent on such factors as its noun origin, the existence of specific unusual unit hoods for finite verb forms. Therefore, one of the prerequisites for determining the part of speech status of the infinitive can be considered the implementation of a detailed analysis of its syntactic functions in comparison with the functions of nouns and finite verbs. But such analysis cannot be the only factor for establishment of the place of the infinitive in the part of speech system. This is because points of joint and impact of the morphological, syntactic and lexical layers of the language belong to the parts of the speech. Therefore, the morphological, syntactic and semantic features of each word form, rather than one of them, must be taken into consideration.

Appliance of the morphological criterion leads to an understanding of the similarity of the infinitive and the adverb through the invariability of the forms of these two language units. If we make use of only semantic features, this will lead to the coalescence of finite verbs, verbal nouns, participles, adverbial participle and infinitive into one class. An attempt to take into account only formally syntactic analysis of this form leads to not less contradictory results. This means that, set a value upon the possibility of a homogeneous classification of the infinitive, its insufficiency can be established.

\footnotetext{
${ }^{1}$ Сучасна українська літературна мова. Морфологія /за ред. І. Білодіда. Київ : Наукова думка, 1969. С. 423.
} 
On the one hand, one might think that in the structure of a sentence the infinitive performs the functions of the following four parts of $\operatorname{speech}^{2}$, like the verb: - Не спати <..> Не спати <...> (А. Дімаров); noun: <..> Бути, а не здаватися кимось - ось один із законів людського існування <...> (Ю. Покальчук); Я хочу знати, любии ти мене <...>; adjective: Зоня знаходить у собі силу репрезентувати на людях родину Річинських (I. Вільде) and the adverb: - Ви посnішаєте взяти в нас групове інтерв'ю? (П. Загребельний). Considering the lexical semantics identical to other forms of the verb, it gives reason to qualify the infinitive as a verb.

Traditional grammars entitle the infinitive not just a verbal form, but also a root verbal form. This point at the infinitive would have to testify the presence of grammatical categories typical for the verb and to prove that the infinitive is capable to perform the primary verbal formal-syntactic and semantic-syntactic functions. However, linguistic studios show that the infinitive refers to such a verbal form, denoting an action without indicating the mood, tense, person, number and gender. This is exactly what led to the focus on the infinitive, as to the indefinite form of the verb. It is often emphasized that the infinitive is the most general presentation of an action and therefore qualifies as the initial, or root verbal form, the centre of the verbal system ${ }^{3}$.

It is known that, according to tradition, units with different sets of morphological features are introduced into the verbal system. It is believed that not all verbal word forms are covered by a complete set of morphological features. this particular approach, according to researchers' point of view, applies to the infinitive. Although the infinitive is void of almost all verbal grammatical categories, it is considered to be the principal part of the verb. Under such conditions, the decisive factor in the qualification of heterogeneous forms is the common character of semantics, rather than morphological and syntactic parameters.

All of the mentioned above proves that the correct grammatical justification of the status of this word form in the system of parts of speech needs to be established on the consistent consideration of its formal syntactic and semantic syntactic functioning ${ }^{4}$.

2 Вихованець І. Частини мови в семантико-граматичному аспекті. Київ : Наук. думка, 1988. С. 284-285.

3 Вихованець І., Городенська К. Теоретична морфологія української мови: Академічна граматика української мови / за ред. І. Вихованця. Київ : Унів. вид-во «Пульсари», 2004. С. 283.

4 Вихованець I. Частини мови в семантико-граматичному аспекті. Київ : Наук. думка, 1988. С. 79-80. 


\section{Processes of the verbal decategorization \\ and verbal recategorizationin the infinitive}

Semantic-lexical parameters make possible to qualify infinitive as a verb. But this definition is obstructed with morphological, formal and semanticsyntactic factors. Without the usage of analytical syntactic morphemes or intonation, the infinitive cannot use verbal syntactic meaning in the structure of the sentence as we talk about the field of syntax, it is not characterized by the means of flexible form of this part of speech. Its semantic-syntactic functions work the same. In the morphological plane the infinitive goes without the most important categories of the verb, such as: the category of the tense, mood, and trans-positional morphological categories of person, gender and number. Therefore, it makes possible to declare, that the processes of verbal decategorization took place in the infinitive.

\subsection{The infinitive and verbal categories of tense and mood}

The infinitive responds negatively to the question about the owning a verbal category of tense. Morphologically, it is deprived of one of the most revealing verbal categories, together with the category of the mood, it conveys the main syntactic category of the sentence - predicativity.

The verbal decategorization of the infinitive is demonstrated in the beyond verbal sphere, or, in its noun, adjective and adverbial functioning. Neutralization of the category of tense, in particular, is observed in the central noun formal-syntactic positions - the position of the subject and the position of strongly governed secondary part of the sentence: Малювати моя мрія; Я люблю малювати; Читати - його бажання; Він любить читати; Співати - ї̈ пристрасть; Вона любить співати.

\subsection{The infinitive and improper verbal categories of person, number and gender}

Grammemes of a person are expressed both by morphological and syntactic means. Since the infinitive answers negatively the question about the presence of a category of tense in the morphological structure, it does not need to be covered by category of person. Of course the question is about its functioning in the syntactic positions of noun, adjective and adverb. In these positions, the category of person is completely neutralized morphologically and syntactically. In the structure of such sentences, the morphological indicators of the category of person are connected not with the infinitive in the positions of the noun, the adjective adverb, but only with the personalfinite forms of the verb, e. g.: Хлопчик любить співати; Він піде працювати.

The category of the person is closely connected with the category of number. It is not a verbal «property» but a result of noun transposition. If the word form has grammemes of tense and mood, then it also has the category of number. The fact that the infinitive is not covered by these categories, as 
well as the permanence of its form, caused the neutralization of the category of number in it.

It is known that the category of the gender is present in the verbs of the past tense, the subjunctive mood, which are always morphologically responsive to the characteristics of the gender of the noun. The infinitive does not require generic differentiation due to the invariability of form and the absence of morphological categories of tense and mood. From a morphological point of view, the infinitive is devoid of morphological categories of person, number and gender transposed from the noun.

\subsection{The verbal category of aspect in the infinitive}

The presence of a verbal category of aspect in the infinitive is considered sufficient requirement for introducing this form into the verbal sphere. The category of aspect, being part of a set of particularly verbal categories, differs by its periphery and implement to the classifying categories.

Insofar as aspect oppositions are implemented within different lexemes, this creates favourable conditions for transposing the category of aspect into all other parts of the speech. The category of aspect, formed on the basis of word-formation, morphological and lexical resources of the Ukrainian language, is characterized by its "easy" transfer to other parts of speech. The infinitive is penetrated by the category of aspect.

However, since the aspect is characterized by the widest range of transpositions and its transfer to the noun, adjective and adverbial base, the presence of aspect correlations (to read-to have read) is not determinant in deciding the part of speech status of the infinitive. Alongside with that, the presence of only one grammatical category of aspect, which, of course, is indicative, but not the main morphological feature of the verb, does not give grounds to recognize the status of the infinitive as the initial (or dictionary) form of the verb. The main forms of the verb are personal-tense and personal-mood forms. In terms of morphology and syntax, they represent the verb as a class of words in the grammatical system of language. Of course, having only one grammatical category of aspect, the infinitive does not manage to "lead" the verb forms.

\subsection{The infinitive and the category of valency}

In noun functioning, the infinitive is distinguished by its internal and external valency. Replacing the noun, this form falls into a valence dependence on the predicate. It should be admitted that the noun infinitive functions in the two central semantic-syntactic positions of the noun - the subjective and objective, e. g.: Співати - його пристрасть; Я люблю співати. With the central semantic-syntactic nominative positions correlate the formal-syntactic positions of the subject and strongly governed the secondary part of the sentence. 
In verbal functioning, the active character of infinitive valency is expressed in the formation of a corresponding semantic position for the actant and its formal representation. The valency of the infinitive covers all the potential arguments provided by the structure of the verb and the conditions of combinability with particular realizers. It can be of two types: left handed (subject) and right handed (object, instrumental, addressee, etc.).The word form of the dative case in sentences with an independent infinitive performs the syntactic meaning of the person. In the modern Ukrainian literary language, the semantically elementary sentence with the infinitive has a hexadic or monadic predicates. This means that the maximum number of nouns in an elementary sentence cannot exceed six components and the minimum number cannot be zero. The infinitive in verb positions, like the verb, plays a major role in the semantic-syntactic organization of the sentence.

The verbal recategorization in the infinitive occurs in the predicative position and the position of the principal part of one-member sentence, which is correlated with the predicate. The specified positions reproduce the definitive verb categories of tense and manner. The infinitive is involved in making a grammeme of the future tense. It also functions in the field of the category of mood, expressing the meaning of the imperative and subjunctive mood.

A convincing proof of the processes of infinitive recategorization is that it is used to express a defining verb category of tense. In the tense category, it is accompanied by analytical syntactic morpheme бути transmits the meaning of time, acting as a necessary component of this grammeme. The analytical form of the future tense of the imperfect aspect is an integral component of the tense paradigm of the verb. The synthetic form of the future tense is increasingly inferior to the analytical one, and hence is gradually weakening its position. In a three-member set of means expressing the grammeme of the future tense, the infinitive with analytical syntactic morpheme is an integral grammatical unity, not a combination of two words ${ }^{5}$, е.g.: - Я буду говорити, а ви слухайте $i$ не протестуйте (І. Вільде). Буду тут працювати, - думає Ніна, прикидаючи, де найкраще поставити стіл (А. Дімаров); - I от ви, рабенятка божі, шамотіла баба, - будете там вічно сидіти і голосочками янгольськими прославляти Господа Бога нашого < ... > (А. Дімаров).

The use of this form as a function of the past tense is characterized by the weak analyticity. Under such conditions, the indicator of the past tense and sudden development of actions, the role of which is played by the analytical

\footnotetext{
${ }^{5}$ Вихованець І.Р. Частинимови в семантико-граматичномуаспекті. К.: Наук. думка, 1988. С. 123.
} 
syntactic morpheme, has a zero form. The infinitive form of imperfective verbs can serve as a predicate, which is interdependent with the subjectnoun. The infinitive in these constructions concerns only verbs with semantics of intensity of action such as to run, to cry, to shout. Amplifying particles ну, ану, давай, used in spoken language, give the semantics of a sudden beginning of the action greater intensity and dynamism ${ }^{6}$ : Дівчина вдарилася - i кричати; Коченя впало - $i$ тікати and Дівчина вдарилася - і ну кричати; Коченя впало - і давай втікати.

The infinitive is characterized by a certain relation to the action and can be used in the function of different grammemes of the category of mood. The infinitive enters the plane of the imperative mood, acting in the forms of both the perfect and the imperfect forms, e. g.: Жодне почуття не встигло народитися у Юджіновій душі, крім одного-єдиного імпульсу-наказу, суворого вміння, холодного і жорсткого розвідницького імперативу: «Стріляти» (П. Загребельний); - Приставити ногу! Справа по одному кроком мари! (А. Дімаров). The infinitives of the imperfect aspect with imperative intonation express more clearly the shade of necessity, and the infinitives of the imperfect aspect are only imperative and determined in time. In addition, the imperfect aspect of the imperative infinitive is addressed to someone in the far prospects, and the perfect aspect is closer to the tense aspect of the action.

The infinitive, used in the form of imperative mood, modifies the aspect semantics, gives a significant degree of expressiveness and categoricity to it. The infinitive usually has inducing intonation that acts as a morpheme mean, е. g.: - Взяти! - крикнув люто. - Бити серед двору в присутності рабів, шеб наука була для інших. А потім закувати - $i$ в ергастул (І. Немирович); Працювать, працювать безумовно! Кожній хвилі нема вороття (В. Сосюра); Учитися! Воихати шумвіків! Рости $i$ розумнішати! Дивитись дедалі все яснішими очима на землю нашу (М. Рильський); «Однаково втечемо! Втікати! Втікати від усіх!» (П. Загребельний).

The infinitive in the form of imperative mood may concern either particular person or may have general character; such constructions contain instructions addressed by an anonymous author (or instructor) to anyone of undetermined number of listeners, e. g.: У випадку аварії розбити скло! Не кантувати! Перед уживанням помімати! Не входити, не постукавши! etc. Their peculiarity inheres in the fact that they express an order not to a concrete but to a potential speaker, the execution of it does not depend on the will of the speaker and cannot be controlled by him/her.

${ }^{6}$ Вихованець І. Частини мови в семантико-граматичному аспекті. Київ : Наук. думка, 1988. С. 124. 
The use of the infinitive as a mean of imperative mood in the expression of military commands is characteristic: - Мовчати! (А. Дімаров);

- Пробиватися до свӧ̈ < ..> У полон не здаватися <..> Потім подивився на мене. - Старшой! (А. Дімаров), special naval commands and etc., е. g.: Циклон загнуздати! Рятувати людей! Не допустити жертв! (О. Гончар).

The form of the infinitive finds its application in the plane of the subjunctive mood. It is realized in it, having a semantic connotation of desire. The subjunctive mood is formed by the infinitive in combination with the analytic syntactic morpheme $\mathbf{\sigma}$ (би), indicative of its use in an atypical function for it, е.g.: $O$, ̈̈м дізнатися б про те ім'я (А. Малишко); Купити б ось яку річ (О. Ільченко); Я до чорта йшов би $і$ до Бога // I життя віддав би на зорі - // Тільки знати б: вічно на дорогах // Плакати не будуть матері! (М. Сингаївський); Поӥхати б знову мені на схід // До славного моря Байкалу (П. Дорошко); Прожить би всі хвилини до пуття (О. Білаш).

In the parallel conditional construction, the infinitive form of the subjunctive mood is often used in one of its parts, and in the second part there is a verb in the personal form of the subjunctive mood, e. g.: $H y, a$ якби перед ним поставити горілку і вино, що б він пив (Ю. Мушкетик). The infinitive form of the subjunctive mood has application in a simple sentence, е. g.: Побачити б (О. Гончар); Полетіти б чорною чортицею під вікно засніжене твоє (В. Малишко).

\section{The infinitive in the formal-syntactic and semantic-syntactic positions of the verb and the noun}

The infinitive is a necessary component of the structure of the compound verbal predicate. The compound verbal predicate has two parts: main and auxiliary. The lexical-semantic basis of the predicate is the infinitives of the finite verbs ${ }^{7}$. The auxiliary part includes personal forms of modal and phase verbs (or adjectives with modal meaning) which elaborate the lexical meaning.

Phase verbs, combined with the infinitive, express externally syntactic categories of tense and mood and internally syntactic categories of a person (gender) and number (function of conjunction). They modify the lexical semantics of the predicate about the beginning, continuation, etc. completed action or state.

For the Ukrainian language, the most appropriate form to characterize the beginning of action is the form «почати» as the main one and its synonyms -

\footnotetext{
${ }^{7}$ Сучасна українська літературна мова. Синтаксис / за ред. І. Білодіда. Київ : Наук. думка, 1972. С. 157.
} 
взятися, братися, кинутися, прийнятися, пуститися etc, e. g.: I, вже хвилюючись, почав пригадувати, що взагалі знає він про Писаренка: прізвище, ім'я, по батькові <..> де працював, де працює <...> (С. Плужник); Вона починає прибирати в кімнаті, а важке, наче висічене з темного каменю, обличчя стає ще сердитішим (А. Дімаров); Степан почав гидливо прочтовхуватись крізь натовп, пхаючись навмання, незважаючи на протести, потупивиись, мов побожник серед відьомського шабашу (В. Підмогильний); Надвечір дівчата почали розходитись (I. Нечуй-Левицький); Мотря заходилась чистить картоплю, а Кайдашиха знов зо сну охала на печі й встала тодi, як надворі зовсім розвиднілось (І. Нечуй-Левицький); Медовар виповнив ковщі, став подавати <..> (П. Загребельний).

The duration of the action is provided by the verb «продовжувати» and its synonyms - залишатися, зоставатися, лишатися, полишатися and etc., e. g.: Хлопи̧і не вгавали кепкувати (В. Забаштанський). Груша все розросталася, Мотря продовжувала ганяти дітей Лавріна (І. НечуйЛевицький).

The meaning of the end of the action is determined by the main verb перестати. The verb кінчати and its synonyms - кинути, припинити, stand close to it e. g.: Зачувии кроки, інші пацієнти кинули шелестіти розмовою й уважно оглядали новоприбулих (С. Плужник); Обурюватись я перестав ще в сьомій клясі гімназї (Є. Плужник); Бідна переконалася, щзо чоловік перестав ї̈ любити, $i$ тепер наосліп шукає призвідника свого нещастя (І. Вільде); «Ще заллє дім $i$ потопить дітей, наче кошенят», - думає з острахом Олена, але перестати прясти не може (І. Вільде); - <..> Бо стоячий чує невтримку і або ж кидає пити, або й зовсім уникає (П. Загребельний).

The compound of auxiliary modal verbs is quite wide. They include not only the modal verbs themselves, but also the verbs of mental and physical action, as they express the valuation of the relationship between the action and the doer ${ }^{8}$.

The authors of the handbook «Синтаксис сучасної української мови: Проблемні питання» (1994 p.) distinguish five groups of modal verbs ${ }^{9}$.

The first group includes the verbs with the meaning of possibility or impossibility: могти, не могти, вміти, встигнути, е. g.: - Хочеш, твоєму коневі вухо можс прострелити? (П. Загребельний). - А я йому відтяла, ш⿻о до нас можсуть приходити листи і без номера (І. Вільде); Не встиг Кайдаш набідкаться, як задній віз нагнався на передній $i$

${ }^{8}$ Слинько І., Гуйванюк Н., Кобилянська М. Синтаксис сучасної української мови: Проблемні питання : навчальний посібник. Київ : Вища шк., 1994. С. 123.

${ }^{9}$ Там само. С. $123-124$. 
перекинувся (I. Нечуй-Левицький); I от, коли я маю ичих засобів більше, коли я можу задовольнити свої потреби краще за інших, - хіба не краще місие посідаю я в житті? (С. Плужник).

The verbs of the second group most often place on modal shades of meaning to the compound verbal predicate - мусити, мати and etc., e. g.: Оце довелось на старість терпіти таку напасть од своїх дітей, промовила Кайдашиха (І. Нечуй-Левицький); Панна Річинська мусить дістати нове свідоитво про лояльність < .. > (І. Вільде).

The verb мати in the Ukrainian language can convey several shades of value of necessity - duty, compulsion, intention, e. g.: - Ви маєте мені щось сказати? - однотонно, якимсь дерев'яним голосом спитав Сквирський, не дивлячись навіть на Івана Семеновича (С. Плужник); sometimes this meaning takes the shade of dissatisfaction: - Але куди б же я мав іти? (П. Загребельний).

The third group of auxiliary modal verbs includes the forms with shades of will - хотіти, бажати, воліти, жадати, мріяти, вирішити, збиратися, надумати, готуватися, пробувати, намагатися, е. g: Господар, поміщик, капіталіст, доктор Гальванеску дуже добре ие знав і саме тому волів шукативиходу $і$ порятунку (Ю. Смолич); Він хотів викричати якусь погрозу, але махнув рукою $і$ занурив губи у ківш з медом (П. Загребельний).

The fourth group of modal verbs is composed with the forms of the value of subjective-modal evaluation - любити, полюбляти, е. g.: Я люблю купувати їх $і$ читати теж (В. Підмогильний);

The fifth group of modal verbs consists of forms with the measuring meaning of ordinary action - звикнути, навчитися, пристосуватися, приладновуватися, е. g.: Що ж, мабуть, дуже скоро люди навчаться робити не тільки дрібні технічні алмази, але й великі діаманти (В. Собко).

The predicate adjectives having a full, or rarely shorter form may also occur the function of modal elements in the compound verbal predicate (повинен, спроможний, здатний, схильний, ладен, рад, зобов'язаний, змушений and etc.), е. g.: Само не спроможне так-сяк $y$ житті влаштуватися, бо безвольне, нікчемне, сопляк якийсь, вибачайте, а тоді й робить з иього мало не вселюдську трагедію! (С. Плужник); А проте він ладен був би благати ї̈ навколішках, коли б вона хоч раз посміхнулася йому, коли б подала йому хоч найменший знак (В. Підмогильний); Хто здатен помогти нам, окрім тебе? (Леся Українка); <..> кнехти реготали до сліз, неспроможнні стриматися навіть перед лицем смерті <...> (П. Загребельний); Ви не повинні мені ставити такого запитання (І. Вільде); Чого це 
вона раптом знову вибирається до Львова, коли, згідно з попередніми планами, вона повинна була б ще мандрувати по Поділлю? (І. Вільде).

The function of modal modifiers of the compound verbal predicate also play the phraseological and established combinations of the type $\mathbf{y}$ змозі, мати право, мати змогу etc. Sometimes such nouns may perform this function мастак, майстер, любитель, е. g.: Він [Йонеску] мастак засмажити риби з яєчнею (Ю. Смолич); «Ви самі розумієте, продовжував Швенд, - що я не мав змоги тримати при собі документи» (П. Загребельний).

Among the one-member sentences, the main part of which is formed by the infinitive, constructions with the rarely used form of the infinitive are distinguished, which indicate the spontaneous phenomena, states and processes. precisely the derivative unit from the similar principal parts of the one-member sentences, rarely used as well, analytical elements act, which lexical part is formed by infinitives, and grammatical and modifying ones are auxiliary phase verbs починас (починало), почне (почало), стане (стало) or analytical syntactic verbal link morpheme бути, е. g: Знову стало накрапати, й вони пішли хутчіше (Є. Гуцало), Стало світати (П. Загребельний); Невпинно переблимувались зірки, десь далеко, край неба, починало червоніти - там сходив місяиь (А. Дімаров). Вже надворі стало світати. Мотря стала оджимать сорочки з відмоки, а Кайдашиха навіть хати не вимела (І. Нечуй-Левицький).

Modal modifiers of type можна, не можна, неможливо, необхідно, доцільно, не доцільно, потрібно, треба, не треба, варто, не варто lower the rank of the infinitive predicate of action and bring it closer to the predicates of the condition, e. g.: Треба було дістати чистий рушник 3 комода, витерти ним, акуратно згорнути $i$ покласти назад (А. Дімаров); Соколів треба було годувати пташками, ставити свіжу воду, шооб купалися і сушилися на сониі (П. Загребельний); Заубуш гаразд відав, щяо не слід довго місити тісто, аби з'їсти пиріг (П. Загребельний).

The semantics of the infinitive can be different. In particular, it can be used to indicate the repeatability, continuity of action: Хіба йому тільки $\check{u}$ робити, що опікуватися нею? (А. Дімаров); its irrelevance: - Завіщо ж дякувати? За те, на шео ви право маєте? (А. Дімаров); absurdity: Куди вже тікати? (А. Дімаров); - Мені дякувати? (П. Загребельний); hesitation: Софія стояла вагаючись: сказати чи не сказати (А. Дімаров); indignation: Перший голос. Не доки ж терпіти се! (Леся Українка); surprise: Андромаха. Що мені чужинці? Чого я маю жалувати ̈̈x? (Леся Українка); helplessness: $А$ за нами - щзо їм лишалось робити? - звелися похмуро й дівчата (А. Дімаров). 
Thus, the verbal functioning of the infinitive is projected into three planes: a) grammatical verbal categories of tense and mood; b) expression of a wide range of subjective modal relations; c) phase demonstrations of action or state. Categorical values of tense and mood, as well as subjective modal relations and phase demonstrations of action either expressed by the infinitive - a combination of it with analytical syntactic morphemes or intermediate between analytical syntactic morpheme and word elements ${ }^{10}$.

Whereas substantiveness is typical to the infinitive, it can be, like the noun, the principal part of the sentence - the subject. For known causes, the infinitive is not able to express the paradigm of the noun flexibly (gender, number, case), and this limits the possibilities of its substantive transposition, regardless of the fact that it is endowed with the positional parameters of the noun.

The infinitive in the predicative function retains its characteristic meaning of the action or state that is not relevant to the subject and does not express the category of tense. The grammatical independence of the infinitive subject is based on the immutability of the infinitive and expresses itself in its position regarding the predicate: - Людей шукати - незле, Ваніку (С. Плужник). In infinitive-subject sentences are used different forms of compound nominal predicate, which are characterized by some general features. The main kinds of infinitive-subject sentences are divided into constructions: Знав тепер добре: Озирнутися - пропасти (П. Загребельний); infinitive-noun: - A підірвати кілька місточків - хіба ие завдання! (П. Загребельний); infinitive-word combination: - Зійтися, заспішив Сквирський, - зовсім не значить кохати щцасливо (С. Плужник); infinitive-category of voice: $-<\ldots>$ a хіба ж збудувати особисте життя - це так просто, що ні ради, ані науки не потрібує? (Є. Плужник).

One of the typical functions of an infinitive in a sentence is an object. There are several groups of verbs combine the object in the form of the infinitive $^{11}$.They are verbs that mean: 1) desire, wish of the subject to perform the action (хотіти, прагнути, братися, збиратися, готуватися, силкуватися, відважитися): Тому Зоня, щцо вона, якраз вона, ніколи не старалася маскувати негативних якостей своєї натури (І. Вільде); Хотіли на нас хреста покласти? (П. Загребельний); 2) agreement, obligation, intention to perform an action (погодитися, домовитися, обіцяти, поклястися, загрожувати, думати, мріяти), е. g.: Мріяла

${ }^{10}$ Вихованець I. Частини мови в семантико-граматичному аспекті. Київ : Наук. думка, 1988. С. 128.

${ }^{11}$ Сучасна українська літературна мова. Синтаксис / за ред. І. Білодіда. Київ : Наук. думка, 1972. С. 198. 
мати, наприклад, білу батистову сукенку в шовкову гратку того самого кольору (І. Вільде); 3) facilitating or obstructing in performong the action (дозволити, допомогти, дати, заборонити, навчити), е. g.: - Пити навчись, хотіти всяк дурень може! (П. Загребельний); - Але мені веліли, - почав був водій, та Зендгер не дав йому докінчити (П. Загребельний); 4) unwillingness to perform an action or avoiding it (відмовлятися, боятися, соромитися), е. g.: Солдати відмовляються воювати (П. Загребельний).

\section{The infinitive in the semantic-syntactic and formal-syntactic positions of an adjective and an adverb}

Semantic compression is one of the main factors that make possible the expression of attributive relationships by the infinitive; It is characterized by certain features. First, it has a more complex nature than that which has the attributive use of nouns and adverbs caused by compression. As for the infinitive, its analogous use is a consequence of the semantic compression of the components of complex sentences, in particular subordinate clauses. Word combinations змога читати, нагода прийти (е. g.: Змога читати допомогла хлопцеві у важку хвилину; Нагода прийти в гості поліпиила настрій усім) with the dependent element in the form of the infinitive on the level of the semantic structure expand into sentences of the following construction: Змога, яка полягає в тому, цоб читати; Нагода, яка полягає в тому, ццб прийти ${ }^{12}$. Second, infinitive substitution of the attribute position on the level of superficial structure is little perceived as a demonstration of semantic contraction. The use of nouns and adverbs in this position, on the contrary, is a direct demonstration of changes in the superficial structure caused by the summarisation of the predicate. Third, the infinitive type of attributes, compared to noun and adverbial, expose occasionality in morphological expression. It is also unregulated in the lexical-semantic content, cf.: Мені належить влада не пускати (Леся Українка). The infinitive expression of attributive relations has no conditions for categorical adjective form. In the modern language, the infinitive can serve as an attribute. Such an infinitive reveals the very essence of the phenomenon or describes a member of a sentence expressed by an abstract noun ${ }^{13}$.

The infinitive in the function of an attribute does not have the inplexional concord, but with its syntactic function is close to those definitions that have lost the ability to show agreement. The syntactic function of an attribute

12 Вихованець І., Городенська К., Русанівський В. Семантико-синтаксична структура речення. Київ : Наукова думка, 1983. С. 197.

13 Там само. 
infinitives can perform in a relatively limited group of nouns, if they, together with nouns, are not the part of the predicate and are capable of conveying an attribute of a concept. Nouns characterized by infinitives of their features, properties, include verbal nouns with the value of will, which transfer modal concepts and, as a rule, are correlated with verbs: - Тобто, поясніть те, що між вами було, що привело вас до наміру розірвати шлюб з вашою дружиною, - уточнює суддя, помітивщи, що Горбатюк не зрозумів ї̈ відразу (А. Дімаров);

If a main noun is preceded by an agreed definition, then it enhances the attributive function of the infinitive: Як романтично розповідав він про віковічне бажання галичан звільнитися (П. Колесник).

Distinctively combined with the infinitive such semantic groups of the nouns ${ }^{14}$ :

1) nounswithseme «спосіб»- мистецтво, манера, метод, наука, досвід, шлях, засіб, закон е. g.: Ідіоти! Сотні мистеитвв розвели, а єдине-мистецтво жити! - занехаяли! (С. Плужник);

2) nouns with seme «можливість», «здатність»- талант, шанс, оказія, секрет, уміння, властивість, змога and etc.: e. g.: Може, тому, що в силі направляти їх і попереду (В. Підмогильний); Навпаки, мені здається, що в наших умовах, коли кожен має змогу розвиватися вільно, особисте життя кожного мало б набрати інших, кращих форм, стати повнішим, иікавішим, змістовнішим <..> (С. Плужник); Забирають соколят з гнізда і привчають платити неволею за ліпше знання волі, за хиже вміння насолоджсуватися нею, осягати іï безмежну обмеженість (П. Загребельний); Винен у тому, щяо не дав Ніні змоги вчитися (А. Дімаров); Що б віддала вона, аби мати можсливість отак сісти у вагон, зайхати кудись далеко-далеко з оцього містечка, від пані Ступакової, від самої себе! (А. Дімаров); А Теа захоплювалася й тим, що Павлуня сибіряк, $i$ тим, що він, виявляється, був танкістом, і його манерою говорити, його суворістю (П. Загребельний); Вони зраділи нагоді знову перетворитися з диких загнаних звірів на людей, посидіти в чотирьох стінах, спокійно посидіти, простягнувши ноги, подивитися на вогонь у печі, послухати тишу за вікнами, погортати книгу (П. Загребельний); Річинський почервонів $i$ наблизився до Олени, а в неї не стало сміливості заперечити (І. Вільде); I раптом виявилося, що не лише вміння працювати ховає в собі слово «робітник» (В. Собко); В ї̈ умінні любити не було нічого штучного, хоч слово «любов» було найулюбленішим ї̈ жартом (В. Підмогильний);

\footnotetext{
${ }^{14}$ Брицин В. Синтаксис и семантика инфинитива в современном русском языке. Киев : Наукова думка, 1990. С. 152.
} 
3) nouns with seme «причина» - привід, резон, смисл, нагода etc, е. g.: Його особисте життя заступило йому все інше; мав рацію докоряти йому Куниия, але чи мав право винуватити, - не певен Іван Семенович (Є. Плужник); Не сердився, бо визнавав ї̈ рацію розуміти його так, як розуміла (Є. Плужник); 3 пана Дулькевича був не який уже там і солдат, але навіть йому набридло сидіти в Англії, $і$ тому він прийняв пропозицію летіти кур'єром до Польщі (П. Загребельний);

4) nouns with seme «право»- привілей, прегорогатива, пільга, е. g.: - Хто дав вам усім право лізти до мене, нав'язувати себе? (Є. Плужник); Після иього всякий має право назвати тебе дурнем, той, хто прогадав, зветься дурнем (В. Підмогильний);

5) nouns with seme «система поглядів» - доктрина, концепція, кредо, норма, норов, звичай, політика, порядок, правило, практика, звичка, принцип, традиція, план, проскт and etc., e.g.: Це була його звичка - загодя радіти перед тим, як мав виректи щось дотепне (В. Підмогильний); Я вже давно переконався, щи дорослі мають звичку з'являтися саме тоді, коли їх найменше чекаєш (А. Дімаров); У нас нема звичаю святкувати іменини чи там народження (В. Підмогильний);

6) nouns with seme «часовий проміжок»-час, хвилина, момент, черга, пора, строк etc, e. g.: Але зовні все було благополучно, так само потроху пробували хворіти то одні, то другі, $і$ їх гнали спершу до лікаря, а тоді на роботу, так само приходив уночі, коли випадала його черга вартувати (П. Загребельний); Час іти на побачення (В. Підмогильний); - Чи ж мені вік коровам хвости крутити? (В. Підмогильний); - Вам надійшов час вибирати? - ступив до нього Сквирський, обкидаючи його гарячим поглядом (Є. Плужник); А може, тобі просто час надійтов по лісі ганяти - $i$ байдуже, за ким саме, чи за Х, чи за У? (С. Плужник);

7) nouns with seme «призначення» - місія, функція, доля, спроба, обов'язок and etc., е.g.: Крім праијі в редакиії, на ньому лежав ще обов'язок доглядати журнала в друкарні (В. Підмогильний); A пізніше, як інериію ту порушено, хіба не робив він спроби все полагодити, спроби будувати своє життя, а не підлягати випадкові? (С. Плужник); - Звідки ви знаєте, де мій дім? - зробив останню спробу оборонятися Отава < .. > (П. Загребельний);

8) nouns with seme «бажання» - мета, ідея, ініціатива, каприз, манія, фантазія, завдання, потреба and etc., e.g.: Як він міг хоч на хвилинку забути товаришів, що там лишились без надії вирватися 3 глушини? (В. Підмогильний); - Ваша величність, яка висока втіха для нас із найсвятішим папою бачити вас і вітати вас, ваша величність! (П. Загребельний); Хай імператриия знає: ї̈ вислухають з найбільшою 
увагою і високо поцінують ї̈ мужність $і$ намір прислужитися святій церкві (П. Загребельний); На якусь мить Ларою оволодіває спокуса провести Олега аж до будинку, де вона живе, показатись із ним пані Ступаковій, але вона вчасно схаменулася $i$ повернула назад (А. Дімаров); Не мати мужності самому говорити за себе! (С. Плужник); «Все», - скінчив він, як розповів про спокусу свою відрядити Сквирського (С. Плужник); Тамуючи в собі бажання зараз же піти звідси, взяв Іван Семенович альбом <...> (Є. Плужник); Андрій Венедович похвалив Степана за його намір учитись, але висловив незадоволення з теперішньої навчальної системи $i$ з того, що від освітніх справ усунено старих, досвідчених педагогів (В. Підмогильний); Так загинула наша надія виростити собаку для прикордонної служби (А. Дімаров). In addition to these nouns, it can be distinguished a number of substances, the combination of which with infinitives is sporadic, stylistically limited, on the edge of normativity, e. g.: проблема - проблема вивчити; місце - місце лягти тощо.

Adjective morphological accomplishment of infinitive syntactic derivation is not possible. The adjective as part of speech are characterized by grammatical categories of the gender, number and case, which are independent, derived from the same categories of the noun. The infinitive is included in the derivation process as a fixed form. The dependency of the syntactic infinitive adjective does not have the conditions for categorical adjective form.

In modern Ukrainian language combinations in which the infinitive performs as the objective determinant are widely used. The infinitive, combined with verbs with a definite spatial meaning, verbs, which are the source of movement, its stimulation, purpose, and less often state, fulfill an independent function of adverbial modifier. The dependent component combines only with the verbs that express movement in a certain direction, е.g.: Вона зруйнувала й гімназію, де він учив буржуйських синків гнобити народ, $і$ кинула, як паџюка, до архіву порпатись у старих nanepax (В. Підмогильний).

From the point of view of the semantics the constructions with the infinitive that expresses the meaning of an aim, are also reduced clauses - it correlates with the clause of purpose. The relations that appear between the components are programmed by the very meaning of the infinitive lexical unit: the corresponding semantics implies combinability with a certain circle of lexical units - the concept of movement requires a definition of its purpose.

The infinitive in the function of the adverbial modifier of purpose, as a rule, occupies the postposition of the verbs with the lexical meaning of 
movement, the purposeful action. The dependent member, the position of which is placed by the infinitive or the infinitive clause, performs a syntactic function of the adverbial modifier of circumstance. It is the main and the only sign of the infinitive in the structures under research, е. g.: Було ще досить рано, але Степан зайшов пообідати до їдальні, що трапилась йому по дорозі (В. Підмогильний); Жінки, що прийшли сюди не тільки слухати музику, ба й показати своє убрання (С. Плужник).

It is proved that the infinitives after not all the verbs with the meaning of movement perform the function of the adverbial modifier of purpose, but only after those denoting movement in a certain direction, e. g.: - Я зайшов нагадати вам, що сьогодні о дев'ятій нарада <... (Є. Плужник); зайшов (where?) - movement in a certain direction; Скрутив велику цигарку і пішов одягатися (С. Плужник); - пішов (where?) - movement in a certain direction.

If verbs mean movement at all, without a certain spatial direction, then they do not generally combine with infinitives. Since the infinitive of all the meanings of adverbial modifier is used only as the adverbial modifier of purpose, apparently it is not a natural function, but acquired in the process of language development.

The optional character of the infinitive is evidenced by the possibility of its elimination without disturbing the structure of the sentence, the free conversion of the infinitive from the dependent member into the dependent part of the sentence with the meaning of the purpose: прийшла провестиприйила для того, щоб провести. In such sentences, the infinitive semantically represents an adjunct, that is, free, not conditioned by valence properties, the distributor of the word, namely: adverbial modifier of purpose. It signals the presence of the situation in objective reality, termed with the help of a personal verb.

Consequently, the verbal expression of adverbial relations is represented by the infinitive. The use of it in the position of the adverb is caused by the semantic compression of the subordinate clause of the complex sentence, which indicates the purpose of the action. The infinitive representation of an adverbial position with the meaning of purpose within the transition verb $\rightarrow$ adverb - is only the demonstration of position assimilation of the verb to the adverb. One of the conditions for the expression of the aim meaning of the infinitive is its use in postposition. In the preposition, the infinitive acquires the quality of relative independence from the sentence, while becoming a complicating component.

\section{CONCLUSIONS}

The infinitive is traditionally called the verbal form because of the referring of so-called general verbal categories to it, although they actually 
belong to verbal categories of trans-positional type, which cannot be considered as indicative in determining the part of speech status of the infinitive. In order to solve the problem of this form properly, first of all it should be taken into consideration its morphological and syntactic features, rather than the verbal lexical semantics common to other forms. In the infinitive the processes of verbal decategorization are in evidence. Verbal recategorization also takes place in the infinitive.

Verbal functioning of the infinitive is directed at the expression of grammatical verbal categories of tense and mood, subjective modal relations, phase demonstrations of action or state. Categorical meanings of tense and mood, as well as subjective modal relations and phase display of an action or state are expressed by the infinitive in combination with analytical syntactic morphemes or border-line between analytical syntactic morpheme and word parts of speech.

In so far as the infinitive is characterized by substantiveness, it can, like a noun, be the principal part of the sentence - the subject. Functioning as a subject, the infinitive does not lose the meaning of the action or state, is not related to the subject, and does not express the category of tense. The object refers to one of the typical functions of the infinitive. There are four groups of verbs which are combined with the infinitive object.

In the adjective plane, the infinitive can perform the syntactic function of an attribute alongside a group of nouns of small quantity, only in case of non-incidence into the predicate together with the noun and in case of the ability to reproduce the attribute of the concept. In adverbial functioning, the infinitive acts as the aim determinant. The infinitive performs in the sentence an independent function of the adverbial modifier of purpose, when it is combined with verbs of a definite spatial meaning, verbs that are the source of movement, its stimulation, purpose, rarely the state.

\section{SUMMARY}

The article deals with the infinitive in the semantic-grammatical aspect. It is proved that the morphological parameters of the infinitive do not afford it to lead the verbal system. The infinitive is associated with processes of verbal decategorization and recategorization. The infinitive penetrated into the field of the four parts of speech. In the plane of the verb, the infinitive is a necessary component of the structure of compound verbal predicate. In the noun sphere, it has the capacity to perform the function of subject and infinitive object. Under a small group of nouns, the infinitive can play the role of an uncoordinated attribute in the sentence constructions. The infinitive becomes the aim determinant with the verbs of movement in a certain direction. 


\section{REFERENCES}

1. Брицин В. Синтаксис и семантика инфинитива в современном русском языке. Киев : Наукова думка, 1990. 318 с.

2. Вихованець I. Частини мови в семантико-граматичному аспекті. Київ : Наук. думка, 1988. 256 с.

3. Вихованець I., Городенська К. Теоретична морфологія української мови: Академічна граматика української мови / за ред. І. Вихованця. Київ : Унів. вид-во «Пульсари», 2004. 400 с.

4. Вихованець І., Городенська К., Русанівський В.Семантикосинтаксична структура речення. Київ : Наукова думка, 1983. 219 с.

5. Слинько I., Гуйванюк Н., Кобилянська М. Синтаксис сучасної української мови: Проблемні питання : навчальний посібник. Київ : Вища шк., 1994. 670 с.

6. Сучасна українська літературна мова. Морфологія / за ред. І. Білодіда. Київ : Наук. думка, 1969. 435 с.

7. Сучасна українська літературна мова. Синтаксис / за ред.. І. Білодіда. Київ : Наук. думка, 1972. 516 с.

\section{Information about the author: Handziuk O. M.,}

Candidate ofat the Philological Sciences, Associate Professor at the Ukrainian Language Department Lesya Ukrainka Eastern European University 15, Prosp. Voli, Lutsk, 43000, Ukraine 